\title{
Organized crime in the field of narco-criminality as a challenge of Western Balkans Countries: a special overview of Montenegro
}

\author{
Ma. Sc. Ridvan Kajtazi \\ PHD Candidate \\ Prishtina, Republic of Kosovo \\ ridvan.kaitazi@gmail.com,Tel: +377 (0) 44700509
}

DOI:10.5901/mjss.2014.v5n19p580

\begin{abstract}
The Balkan region is an integral part of the "new" European environment. However, the involvement of the Balkans region in the new European architecture has been particularly problematic, with negative consequences for the entire European space and for the evolution of European integration. The process of transition and recovery now underway in many Balkans states, following years of conflict and instability, has given rise to new challenges for the region. In the political sphere, the main challenge has been the establishment of a liberal democracy, given that most countries in the region were only "partially" democratic before the Balkans conflict. A second important challenge has been to establish a positive identification of the state by its citizens. In the social field, one can observe weak organizational capacity on the part of social actors, and an underdeveloped civil society. In this context, the presence of organized crime has a particularly detrimental effect on the development, stability and security of the Balkans in general, and it poses a challenge to the state apparatus and a major obstacle for legal, political and economic reforms. Organized crime is an open and extremely painful wound in human society around the globe. Distinguished experts in this field consider the Balkans Peninsula to be an entry gate for organized crime in Western Europe. Therefore, organized crime not only presents a risk for individuals and the society within a specific country, but it also presents political problem across countries. In this part of our Peninsula, Montenegro plays a key role. However, this fact does not exclude the reality of cooperation between Serbian, Italian, Greek, Russian organized criminal groups, which are the main transporters for narcotics, since many organized criminal groups are composed of the different ethnicities. In an effort to clearly present a picture of this phenomenon, the present paper will firstly present research which is key to understanding the criminal structure of organized crime groups in Montenegro. In addition, this paper will examine the cooperation that exists between organized crime groups in Montenegro and other international groups, including their interests in criminal activity generally, and the field of narco-criminality in particular.
\end{abstract}

Key words: state, organized crime, Montenegro, criminal groups, narco-criminality, etc.

\section{Introduction}

With the collapse of communist regimes in Eastern Europe and beyond, and as part of the euphoria for union followed the Maastricht Treaty, a perspective of a future of a united Balkans seemed possible in a democratic Europe. After the fall of communism, all Eastern European countries were forced to undergo a double transformation, where the most important challenges to be faced were economic transformation and political democratization. Despite these transformations, some other issues were of importance to the situation in the Western Balkans. In that period, the main concern of the region was mainly related to "state-building", in the true sense of the word, although with different profiles for individual cases, starting from a weak state, with an unfinished state-building in Albania, to building up the state and nation in Yugoslavia.

Re-focusing attention on the issue of nation-states could result in disturbances for the whole region, where the dissolution of the Western Balkan countries constitute the most acute problem to be faced. Apart from the dissolution of Yugoslavia, the state of Montenegro went through difficult periods of disturbance. These developments in the region are often referred to as the process of "Balkanization". This phrase aims to describe the situation of the Western Balkans countries in the 1990s, with the dissolution of Yugoslavia and failure of the state in Albania being the last phase of the process of dissolution. 


\section{Challenges of the Western Balkan countries}

As noted above, the process of transition and recovery from the Balkans conflict, and related instability, brought new challenges for the region. In the political sphere, the main challenge has been the establishment of a liberal democracy, due to the fact that most countries in the region were "partially" democratic. The second important challenge has been to establish a positive identification with the state by the citizens. In the social field, a weak organizational capacity of social actors and an undeveloped civil society has been notable. Organized crime has a harmful impact on the development, stability and security of the Balkans in general, and it poses a challenge for state mechanisms and a major obstacle for legal, political and economic reforms.

A number of issues are threatening European security overall, particularly transnational organized crime, international terrorism, ethnic and religious conflicts, trafficking of human beings, drugs and weapons; all these issues are thriving in an environment of political uncertainty and economic deterioration. The stability in the Balkans is ruined with criminal networks, and therefore this issue is a major challenge for the European Union. Success is not only important for the interests of European security, but also will serve as a model for elsewhere. The EU Strategy, "A secure Europe in a better world", adopted by the European Council in December 2003, notes that Europe is the main target for organized crime and lists it as one of five "main threats" until European Union. The EU Security Strategy considers that "restoring good governments in the Balkans, encouraging democracy and enabling the authorities to tackle organized crime, is one of the most effective ways to treat organized crime within the EU". The EU has adopted an integrated approach for the region in fighting against organized crime in the Balkans, however, this strategy lacks an effective system of operation and practice, and a targeted approach for each specific form of trafficking. It is an undisputed fact that the largest amount of drugs brought from Central Asia passes through various Balkan states, as transit places to the rest of Europe. The use of these routes for drug trafficking and other smuggling is not only due to the appropriate geostrategic position of these states, but also due to the extremely low level of professional police and customs services of these countries. Thus, easily corruptible state officials, and inadequate legal treatment of these criminal activities, has meant that narco-criminality has become very dangerous and harmful for the society in general and in particular for individuals and our families.

Activities of criminal groups are also becoming more complex. The current trend is for a free network of cooperation between various criminal groups, and above all, inter-ethnic cooperation instead of rivalry. According to reports of the European Police (Europol), Organized Crime (2005 and 2006), "Albanian speaking" organized criminal groups will likely gain the majority control of the illegal drug market that is being developed in some European countries. ${ }^{8}$ According to the United Nations Office on Drugs and Crimes, about $70 \%$ of the heroin that enters Germany and Switzerland passes through the western Balkans, and is brought by Albanian criminal groups. ${ }^{9}$ From Albania alone, about 30 tons of cocaine passes yearly in direction to EU by air routes. ${ }^{10}$ Many authors emphasize the fact that organized crime is also supported by politics. Thus, combating organized crime must be one of the first priorities of the governments of the Balkan countries.

\section{Legal and Politic transition of Montenegro}

Montenegro is a country in Southeastern Europe; it has a coast on the Adriatic Sea to the south-west, and is bordered by Bosnia and Herzegovina to the northwest, Serbia to the north-east, Croatia to the west, Kosovohttp:/len.wikipedia.org/wiki/Montenegro to the east, and Albania to the south-east. According to the Office for Statistics in Montenegro, the total number of people who live in territory of Montenegro in 2011, was 620,029 thousand. The highest percentages of persons are aged between 15-64 years, amounting to $68.1 \%$ of the total population. The result of first free elections in Yugoslavia since World War II, held in 1900, set the stage for civil war that broke out in summer and fall 1991.11 After the dissolution of the SFRY in 1992, Montenegro remained part of a smaller Federal Republic of Yugoslavia along with Serbia.

In the countries of Southeast Europe today, which dictate the largest part of the agenda of security in Europe, there are three types of security threats. Rather, they are "broken" through various and numerous coalition compromises, which make them a very distant reflection of the political will of the citizens. ${ }^{12}$ In other words, the current structure of government in most countries of Southeast Europe is partly illegitimate. As the governments do not or reflect the attitudes of its citizens, the political elite are therefore forced to fight for survival - and for the survival of those who govern political life - through unhealthy compromise with coalition partners and other influential individuals and groups. In short, the integrity of such political elite is compromised, and they cannot be a reliable source of social stability, or individual security, for citizens. This kind of insecurity threatens an individual citizen in a manner that is in theory known as "Dominion threat". 
After eight years of independence, Montenegro is still undergoing transition within all institutions of government. However, a main focus has been on economic development and fighting crime, especially organized crime such drugs trafficking, human trafficking, money laundering etc. Among Western Balkan countries in particular Montenegro cannot be considered to have substantially more disaggregated crime overall, though the level of crime is increasingly being raised. However, the increased tendency for crime to be "dangerous" is clearly observed in reports published by Europol and Interpol. Until the announcement of an independent Montenegro through referendum, the country was known as "the exporter and importer" of stolen luxury cars in European countries, the USA, and Asia, as well as from countries of the Balkan Peninsula towards the countries of the Middle East.

All countries of the West Bank in particular Balkan countries which are detached from the clutches of the Yugoslav regime still rely on nepotism, support and funding of political parties by "dirty" businesses run by organized crime. Also, the situation when an affiliate of many law enforcement institutions, we involved the Yugoslav regime in criminal groups, paramilitary and military order lifting and reaching unbridled desires Yugoslav regime, especially from 1990 onwards has created a situation usually not because, first considered criminal groups must fight organized crime that are within about themselves within the state apparatus thereafter combat criminal groups that have nothing to do with the state apparatus, so exit from this abyss without moral accountability political, legal and political influential persons, and holders of the public institutions in Montenegro has led to an unstable situation for the fight against organized crime. In 2002 Serbian criminologist Dobrivoje Radovanovic reported that the infrastructure of criminal organizations, which was promoted intentionally by government authorities in the 1990s, remained intact:

"... it is true that the police have been largely responsible for the existence of organized crime in our country since 1992. The State Security [Service] to be precise. They invited prominent underworld bosses to be their associates in the battle for the Serbian national interests in Bosnia, Croatia, and other parts. The secret police was through them involved in the plundering, war crimes, and war profiteering. They enabled every prominent criminal to have a DB [Security Service] identity card. A consequence of that was the overlapping of the secret police, the underworld, and the police. ${ }^{13}$

\section{The concept of Organized Crime}

The definition of organized crime varies from agency to agency, from state to state. The joint plan of the European Union of $21^{\text {st }}$ December 1998, has determined that in all member states, a 'criminal organization' will be called the organization that has a structure, consisting of two or more persons, designed to operate for a certain time and commit crimes for which the law provides a minimum of 4 years imprisonment or more severe punishments.

Organized crimes must be considered as crimes committed in criminal groups, and several conditions must be filled; of these, four key elements must exist:

- Collaboration of three or more persons;

- Their criminal activity for a long time;

- Committing crimes with serious risks;

- With the aim of gaining wealth; ${ }^{14}$

Organized crime has a proper organized structure, in which the interest of operations is focused on a relatively large number of criminal acts, starting from: trafficking of drugs, prostitution, money laundering, illegal privatization of public enterprises, threat, trafficking of weapons and ammunition, smuggling cigarettes, trafficking in stolen vehicles, robberies, kidnappings, trafficking in persons, art thefts, murders etc. Trafficking of drugs and human beings, as known, hold the first place in the profits made by criminal organizations. ${ }^{15}$ Violating the interest of criminal organizations that deal with trafficking of drugs causes violence and unimaginable consequences between criminal groups; typically, these groups are rivals to each other in terms of ownership of different markets to sell drugs. ${ }^{16}$ As can be seen, all countries in the region face many challenges. However, Montenegro is on its way to establishing rule of law, and fighting against criminal activities and basic causes of crime. Thus, for example, in April 2003, the government of the Republic of Montenegro adopted an 'Action Plan' for preventing drug addiction of children and youth in Montenegro, based upon coordinated acting of the Officials of the State Administration, Units of the Local Self-Governance, Associations, citizens, Legal and Physical Persons. 


\section{A. Organized crime in the field of narco-criminality with special overview in Montenegro}

The existence of organized crime in Montenegro can currently be expressed only through the statistics of criminal offences with the elements of organized crime..$^{17}$ Organized crime is mainly invisible and often closely connected to the legal economy..$^{18}$ Organized crime in Montenegro is similar like other parts of Europe, and the region is expanding its network into different types of trans crimes, including a large variety of criminal activities. As such, organized crime presents more and more a combination of low-risk and high-risk activities, by creating flexible international relations which can easily adopt and respond to the strategies of law enforcement. In addition, organized crime is exploiting legal economic activities in order to legitimize their criminal activities and applying high technology, especially for hiding and encrypting communications. ${ }^{19}$ The reports and analysis of the regional and international police organizations and other law enforcement agencies in the countries of the region, as well as the current practice of the Police of Montenegro, indicate that organized and serious crime is very difficult to detect. The collection of evidence is complex, especially in cases of transnational crime. Preventing and fighting serious and organized crime, therefore, receives a high priority on the political agenda, especially with the view to future accession to the EU, and the need to align the standard and practice for fighting organized crime, UN conventions, conventions and recommendations of the Council of Europe, directives and decisions of the EU framework, and responding to other international standards. ${ }^{20}$ Smuggling and trafficking of narcotic drugs is the main activity of the organized crime in Montenegro. The most common types of drugs that are subject to the business of organized criminal groups are heroin, cocaine, and marijuana (cannabis). In relation to the estimated amounts of drugs smuggled by the OCG from Montenegro, it can be concluded that Montenegro is, to a lower extent, the final destination, but that it is mainly a transit zone. In some cases, it has only the role of a logistics base for the organization and implementation of the activities designed abroad. ${ }^{21}$

\section{IV.A.1. The groups of Organized Crime in the field of Narco-Criminality in Montenegro}

According to specialists of the State Police and Intelligence Agencies, there are considered to be certain organized crime groups in Montenegro. The priority activity of these groups is trafficking of drugs. Indeed, the existence of these groups is logical, given that Montenegro represents an important link in Balkan road of transportation narcotics. If one considers the global map of narcotics trafficking, there are three main routes of trafficking from Africa or Asia involving the Balkans region. These routes are as follows:

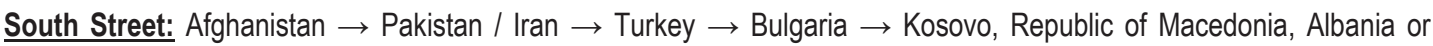
Montenegro $\rightarrow$ Italy.

Central Street: Afghanistan $\rightarrow$ Pakistan / Iran $\rightarrow$ Turkey $\rightarrow$ Bulgaria $\rightarrow$ Republic of Macedonia, Montenegro, Serbia or Bosnia and Herzegovina $\rightarrow$ Slovenia or Croatia $\rightarrow$ Italy.

North Street: Afghanistan $\rightarrow$ Pakistan / Iran Turkey $\rightarrow$ Bulgaria Romania Hungary or Ukraine $\rightarrow$ Austria, Slovakia, Poland or Germany. ${ }^{22}$

Therefore, one of the most critical and important aspects to be examined in this research paper is the organizational structure of those criminal groups operating in the territory of Montenegro. According to a publication on the "Novinar Online" web portal, which has a publication date of 17.05.2007, Montenegrin police compiled a detailed list of all criminal groups in the country and abroad; it totaled 700 criminals. Whereas Serbia had the 'White Book' of organized crime, Montenegro has made the 'Blue Book' of Montenegrin mafia. The 'Blue Book' is printed in one copy only, and it is kept in the safe of the Staff Director of the Police. Last week, Veselin Veljović, Director of the Police, gave an insight into this just finished list to members of the Parliamentary Committee on Security. The 700 named criminals operating in Montenegro are involved in approximately eight organized criminal gangs - in Podgorica, Bar and Rozaje there are two gangs, and in Niksic and Berane, respectively, one. ${ }^{23}$

\section{IV.A.1.1. Podgorički Klan 1}

In the capital of Montenegro there are a number of criminal groups. Among them, a group led by brothers Gjurasevic stands out in terms of organizational structure and financial power. This group "specializes" cross-border drug smuggling from other West Balkan countries. The group is occasionally engaged in weapons smuggling, and the activities 
were expanded to include the smuggling of expensive cars from Montenegro to Albania and vice versa. They are connected with other organizations in Podgorica, Bar and Niksic, and Serbia and Croatia. ${ }^{24}$

\section{IV.A.1.2. Podgorica Klan 2}

Podgorica has the second criminal group managed by the brothers Dresaj. This group specializes in the smuggling of hard drugs from Albania to Montenegro. Organizationally linked, the brothers Gjurasevic together control the transit of narcotics through the territory of Montenegro and the former Yugoslav republics, achieving cooperation with other groups in Montenegro, Albania, Croatia, Bosnia and Kosovo. ${ }^{25}$ In a police operation called "Viper", which took place on 25 August last year, the brothers Dresaj, together with M. Gjurasevica and G. P. from Shkodra, were arrested for unauthorized production, possession and distribution of narcotics. ${ }^{26}$

\section{IV.A.1.3. Baran Klan}

The Podgorica groups are closely linked to Baran, who, according to police, have recently taken over the Montenegrin underground. The Bar clan has a higher level of organization, and significant financial resources and logistics in the wider area of Montenegro, Belgrade and abroad. ${ }^{27}$

\section{IV.A.1.4. Niksicki Klan}

The Niksicka group, the so-called "Kvartasi", is involved with drugs smuggling, according to police sources, this group works with most of the Podgorica and Baran groups, and "colleagues" from the Serbian Republic. Also noteworthy is the "Rozaje group", in terms of connections with criminal structures in neighboring countries, as well as the financial power. This group is mainly engaged in the sale of heroin from Afghanistan and Turkey. ${ }^{28}$ The strength of these gangs, clans and individuals, according to the conclusions of the National Security Agency of Montenegro, means that they are linked not only with European and international mafia, but with parts of the political structure itself in Podgorica. ${ }^{29}$ There is also the possibility that criminal structures associated with individuals from the Montenegrin state bodies and institutions could provide logistical support for their criminal activities. It should be borne in mind that such a phenomenon could have very serious consequences and significantly slow down the process of reform of the Montenegrin society. ${ }^{30}$

\section{IV.A.2. Trend of narco-criminality in Montenegro}

In relation to the area of operations, the criminal activities of organized groups in Montenegro can be roughly divided into two main

forms:

- $\quad$ Smuggling through the territory of Montenegro and local drug distribution: where the organization and realization is connected to the territory of Montenegro.

- Transcontinental smuggling and smuggling through the Balkan route and distribution in the European countries: where the realization of the criminal activity is conducted relatively far away, but the organization, at least one part of it is conducted at the territory of Montenegro. ${ }^{31}$

Organized crime groups in Montenegro are involved in trafficking of certain types of drugs which generally reflect the special interests of those groups.

\section{IV.A.2.1. Trafficking of Heroin}

Montenegro has major seaports and remote mountainous borders with Serbia, Bosnia and Herzegovina, Albania and Kosovo. Despite this, it is difficult to find evidence of large scale heroin trafficking in the country. The small volumes seized have declined since 2009 and average less than $10 \mathrm{~kg}$ per year. ${ }^{32}$ Apart from a handful of exceptions, neighbors of Montenegro have not reported receiving even medium-sized shipments of heroin for further trafficking in recent years. This is supported by Montenegrin law enforcement, which reports that, "a decline in heroin business is observable" and adds 
that, "[i]n the case of heroin it is quite characteristic to smuggle it in smaller packages ranging from 2 to 5 kilos. In contrast, cannabis shipments transported through the country and continuing northward are on the increase."33

Local organized criminal groups in Montenegro are likely to be bypassed and/or excluded from the land heroin route by the Albanian organized crime groups, unless they strengthen their "alliance" and offer favorable conditions for the transport of heroin through Montenegro, as compared to the competition in the region. The latest confiscations of heroin in Montenegro, by their quality and quantity, indicate that they were mainly intended for street sale, and not further smuggling to the EU countries. This is confirmed by smaller confiscations of heroin in the neighboring countries, whose transport was organized through Montenegro, suggesting that this channel is used less and less. ${ }^{34}$ In Montenegro in 2011 there are 1, 283 heroin users, is big problem to have the exact number of the users of opiates or other drugs..$^{35}$

\section{IV.A.2.2. Trafficking of Cocaine}

At a higher level, organized criminal groups from the Western Balkans have established operational bases in Latin America, maximizing their profits by sourcing cocaine directly from producers. ${ }^{36}$ Groups from Serbia and Montenegro in particular have been involved in such trafficking activities, exploiting links and associations with Southern Cone countries in South America. ${ }^{37}$ Often, these groups do not traffic cocaine though South-Eastern Europe, but the proceeds may be laundered in the region. In recent years, Bulgarian, Serbian and Montenegrin sailors have often been implicated in cocaine trafficking from Latin America to the ports of Antwerp and Hamburg. The biggest damage Montenegro suffers is due to the criminal activities of cocaine smuggling, which is operated worldwide by several dozens of criminals originating from Montenegro, out of which a certain number are not Montenegrin citizens. In this way, organized criminal groups are increasing their financial power and influence. Because of the widespread network of contacts at key points, where criminals are originally from Montenegro engaged in organizing parts of cocaine smuggling and distribution, the consequences of a failed job, errors or fraud that occurred abroad, may result in violence against members of the group or close associates in the territory of Montenegro. ${ }^{38}$

According a publication in "The Guardian", which is web portal, "....Customs officers in Montenegro have seized $250 \mathrm{~kg}$ of cocaine smuggled beneath a shipment of bananas, authorities described as the biggest drugs haul ever, the cocaine was worth about $€ 12.5 \mathrm{~m}(£ 10 \mathrm{~m})$ and was seized in the southern port of Bar, a well known transit route for South American drugs heading to Europe...." 39

\section{IV.A.2.3. Trafficking of Marijuana (Cannabis Sativa)}

According to the UNODC annual reports questionnaire Cannabis trafficked into Montenegro and Serbia comes from Albania and about half of this amount remains there, with the rest continuing on to Bosnia and Herzegovina and Croatia. Albanian cannabis is also trafficked to Italy and Greece. Cannabis production in the southern areas of Albania is believed to be destined almost exclusively for export to Italy. Albania as a country which is the direct neighbor of Montenegro, and as a producer, has the most negative impact that on the local market in Montenegro. Marijuana is present in sufficient quantities, at low prices and easily accessible to the younger generation, the highest-risk category for this type of drugs. ${ }^{40}$ Due to the relatively easy available "skunk" in the neighboring Albania and the possibility for quick profit gains in short period, the smuggling of these types of drugs through Montenegro became a criminal activity in which mostly new, and usually temporarily affiliated individuals, are included. Cannabis herb is said to be trafficked by road from Albania through the Former Yugoslav Republic of Macedonia and Bulgaria to Turkey. About 20 per cent of cannabis herb that is trafficked in Croatia is domestic in origin, with the balance being brought into the country from Bosnia and Herzegovina (about half of the total), Montenegro, Serbia and other countries. ${ }^{41}$

About half of this remains in Croatia, while the rest is sent on to Western Europe. All domestically produced cannabis is consumed in the country, however. ${ }^{42}$ In Montenegro, law enforcement seizures cannabis herb in 2011: 804 kilograms and in 2012: 1,022 kilograms. ${ }^{43}$

\section{IV.A.3. Drug use among the general population and young people}

Drug use among young people was fairly limited in Montenegro until approximately the end of the 20th century, and the social and health impact was similarly restricted. However, in the mid-1990s, drug use started to spread quickly (which was later than in neighboring countries), and by the start of the 21 st century, the use of illicit psychoactive substances 
had become a significant public health issue. Surveys on drug use among the general population have not yet been conducted in Montenegro. Research conducted in 1999 by the Health Protection Bureau among a sample of 4054 primary and secondary school students from across the whole of Montenegro revealed that $3.1 \%$ of all participants had tried a drug in their lifetime $-0.4 \%$ among primary school pupils (11-14 years old), and $6.7 \%$ among secondary school pupils $(14-18$ years old $) .44$

According to Ministry of Health for Montenegro, in 2004, the Public Health Institute of Montenegro conducted a national survey with a sample of 3964 pupils from the fifth grade of primary school to the fourth grade of secondary school (11-18 years). This corroborated an increase in drug use $-5.8 \%$ of respondents had ever used a drug in their lifetime, more specifically $2.3 \%$ of primary schools pupils and $10.1 \%$ of secondary school students. Some $77.6 \%$ of students who had experimented with drugs were from secondary school, with the highest percentage in the second grade (30.6\%). Most children first tried drugs in the upper classes of secondary school (third grade of secondary school $28.7 \%$, and fourth grade of secondary school $24.6 \%$ ), but $1.6 \%$ of children first took drugs in the fifth grade of primary school. Drugs were most used in the southern region (4.7\%), somewhat less in the northern region (4.1\%), and least in the central region of the country $(3.8 \%){ }^{45}$

According to the European Monitoring Center for Drugs and Drugs Addiction, the European School Survey Project on Alcohol and Other Drugs (ESPAD survey) was implemented for the first time in Montenegro in 2008, by the Public Health Institute in cooperation with the Council for Information and Other Drugs (CAN) and with the European Monitoring Centre for Drugs and Drug Addiction (EMCDDA). The target population was students born in 1992. A complete population of first graders from all secondary schools was taken as the survey sample in Montenegro. The final sample size comprised 7557 students. Results of the survey showed that, excluding alcohol and tobacco, the most frequently used (illegal) psychoactive substances were marijuana and inhalants (life time prevalence of $4 \%$ each), followed by tranquillizers/sedatives. ${ }^{46}$ Estimates of problem drug use, defined as 'injecting drug use or long-duration/regular use of opioids, cocaine and/or amphetamines' relevant for the whole country are not available. Very limited information is available in Montenegro on the research study among injecting drug users conducted in 2005/2006 that attempted to estimate the number of injecting drug users in Podgorica (Simic et al., n.d.). The research was financed by the UK Department for International Development, and implemented by the Imperial College in cooperation with the United Nations Development Plan (UNDP) Serbia and Montenegro, the Public Health Institute of Montenegro, and the NGO Juventas. ${ }^{47}$

According to the available results, the crude estimate of the capture-recapture study was 950 injecting drug users (95 \% Cl 675-1 455) in Podgorica. The under-reporting and the misclassification of identifiers produced unrealistic sparse overlaps among the three sources, so crude estimates were inflated. According to the estimates based on validated and adjusted counts, the number of injecting drug users was 660 (95\% Cl 520-909) in Podgorica, $0.7 \%$ of the 15- to 49year-old population. It should be noted that the police data contained a larger percentage of women than the other two sources based on voluntary participation (20\% in the police versus $7 \%$ in the survey and $4 \%$ in the drug treatment data). ${ }^{48}$

According in the annual report of Internal Ministry of Montenegro, in 2002, there was total number of 6950 criminal charges submitted against 5542 persons. Within the field of combating against narcotics, 305 criminal offences were registered (223 illegal manufacturing and trafficking with narcotocs - Article 245 of previously valid KZ of SJ and 82 enabling to use narcotics - Article 246 of previously valid KZ of SRJ).1.741.487,05 gr of narcotics were confiscated.

In the year 2003, 295 criminal offences were detected concerning narcotics, namely: 207 criminal offences of illegal manufacturing and trafficking with narcotics and 88 criminal offences of enabling the use of narcotics. ${ }^{49}$ Criminal charges were submitted to the competent Prosecutors against 276 persons; from these persons $875.336,6 \mathrm{~g}$ of narcotics were confiscated, out of which most was marijuana $(862.500,49 \mathrm{~g}$.) and heroin $(12.210,11)$. In the Year 2003, the increased use and presence of heroin was noticable, and confirmed by confiscated quantity. ${ }^{50}$

According in the annual report of Internal Ministry of Montenegro, in 2007, there were 491 illicit drug seizures, totaling 289.2 kilograms. In 2008 , there were 390 seizures, totaling 353.3 kilograms (an increase of $24 \%$ in the quantity of drug seized). An increase can be observed in the seized amounts of marijuana (19.8\%), heroin (90\%) and cocaine (19.9 $\%$ ), of the total number of suspects reported to the Prosecutor's Office and those against whom criminal charges were brought for criminal acts under the jurisdiction of the Higher State Prosecutor, the ratio of people against whom criminal proceedings were started for criminal acts related to drugs is over $60 \%$. As regards individuals imprisoned for drug law offences, data from the Institute for the Execution of Criminal Sanctions Podgorica indicate that the trend is for a constant increase in the number of convictions between 1995 and 2008. With the exception of 2002, this figure rose constantly and 
it stabilised at approximately one quarter of the total number of people sentenced, while in 2007 it reached almost one third, and in 2008 the proportion was even higher.

In 2010, the total number of reported offences was 10033 , of which 262 were reported for offences under Article 300 and Article 301 of the Criminal Code. Requests for the investigation were initiated against 2923 persons, of which 259 for the offences from Article 300 and Article 301 of the Criminal Code. Some 5588 persons were convicted, of which 272 persons were convicted under the Article 300 and Article 301. Judicial decisions have been made against 7014 persons, of which 343 for the offences under Article 300 and Article 301 of the Criminal Code. ${ }^{51}$

\section{IV.A.4. Legal framework in Montenegro that regulates the fight against narco-criminality}

Criminal offences related to the production and trafficking of narcotic drugs are stipulated by the Penal Code of Montenegro, in Chapter XXIV—Criminal Acts against Human Health (which indicates that the protective object of all forms of criminal deeds in this chapter is human health) (Official Gazette of Montenegro, No 70/03 No 70/2003, dated 25 December 2003). There are two statutory criminal acts related to drug abuse in the Penal Code of Montenegro: unauthorized production, keeping and trafficking of narcotic drugs (Article 300), and facilitation of consumption of narcotic drugs (Article 301).

Amendments to the Penal Code (Official Gazette of Montenegro, No 25/2010 dated 5 May 2010) are laid down in Article 300 of the Penal Code. This article contains seven paragraphs. Article 300 stipulates that 'Anyone who unlawfully produces, processes, sells or offers for sale, or who for the purpose of selling buys, keeps or transports or mediates in the selling or buying, or in some other way unlawfully releases for circulation the substances or preparations pronounced to be narcotics, shall be punished by an imprisonment sentence of two to ten years'. Personal drug use is not sanctioned by the Penal code of Montenegro, nor is drug possession for personal consumption. In the frames of description of criminal acts related to drug misuse, the Penal Code of Montenegro does not classify individual drugs.

In 2009, the Parliament of Montenegro adopted the Law on Precursors for Narcotic Drugs (Official Gazette of Montenegro No 83/09). This Law is aimed at monitoring and control of manufacturing and placing on the market of substances which can be used in the manufacture of narcotic drugs and psychotropic substances in order to discourage their diversion or use for illicit purposes, as well as to protect people's lives and health and environment from harmful effects of precursors.

In $3^{\text {rd }}$ of June 2011, The President of Montenegro, decree on proclaiming the law about preventing drugs abuse. This Law set out the measures for preventing the use of illicit drugs and for dealing with users of illicit drugs. The measures cover informational, medical, educational and consulting activities, medical treatment, measures for rehabilitation, social security services and programs for the resolution of social problems related to the use of illicit drugs and monitoring of the consumption of illicit drugs which will be carried out by the competent ministries.

Montenegro has both a national drug strategy and an action plan for implementation of the strategy. The Government of Montenegro, adopted the following documents: the National Strategic Response to Drugs 2013-2020 and, as its integral part, the Action Plan 2013/2016 for Implementation of the Strategy. The strategy represents a continuation of previously completed work in the field of drugs in Montenegro. The objectives of the national strategy are both general and specific.

\section{IV.A.5. National, Regional and International obligation of acting for Montenegro}

The war of fighting an organized crime, need more national, regional and international obligation of acting to win betel against smugglers and drugs in general. Montenegro has international obligations to respond and in below they are some conventions, regulation:

- $\quad$ Unique Convention on Narcotics, from 1 August 1961, amended by Protocol, from 25 March 1972;

- $\quad$ Convention on Psychotropic Substances, from 21 February 1971;

- $\quad$ European Convention on Fighting Against Terrorism, from 27 January 1997;

- Convention on Protection of Human Rights and Fundamental Freedoms, from 4 December 1950 and belonging Protocol. 
- Convention on Laundry, Following, Depriving and Confiscation of Incomes from Criminal Offences, from 8 November 1990;

- International Convention on Combating Financing of Terrorism, from 9 December 1999;

- $\quad$ Roman Statute of the International Criminal Court.

- $\quad$ Convention of UN on Fighting against Illegal Trafficking with Narcotics and Psychotropic Substances, from 20 December 1988;

- Declaration on Intention on Legal Definition of Victims of Trafficking with Human Beings, elaborated in Tirana on 11 December 2002 within the frame of Stability Pact for SE Europe, which among others contains :

- $\quad$ Anti-Trafficking Declaration of SE Europe signed in Palermo on 13. December 2000;

- Protocol of UN for Preventing, Combating and Punishing of trafficking with human beings, especially Women and Children, as Supplement to the Convention of UN for fighting against Transnational Organized Crime (15 November 2000), which obliges participant Countries to "examine introducing of legal and other appropriate measures", which would enable trafficked persons "to stay at their territory, temporary or permanently, in appropriate cases";

- $\quad$ Trafficking with Women with the Aim of Sexual Exploitation (26 April 1997), which recommends establishing of privileged residence status for trafficking victims during the criminal proceedings.

- Decision Nr.1 of Council of Ministers of OESCE on increasing efforts of OSCE in fighting against trafficking with human beings (28 November 2000) to " examine introducing of legal and other measures, like shelters, which would allow victims to stay at their territories, temporary or permanently, in appropriate cases";

- Hague Ministerial Declaration on European Directives for Effective Measures for Preventing and Fighting against;

- Recommendations of EC R (2000) 11 for Action Against Trafficking with Human Beings with the Aim of Their Sexual Exploitation (19 May 2000), which invites all member Countries to assign to the victims " temporary residence status in the Country in which they are...in order to allow them to be witnesses in the Court proceedings against accused", also in order to provide victims with on time social and medical care;

Priorities for implementing of National, Regional and International obligations are:

- Developing of operative mechanisms based upon EU (SAP) standards;

- Cooperating among States aiming organizing of joint operations against organized crime and exchange of information;

- Harmonization of legislation according to JHA standards;

- $\quad$ Active participation in all activities within the frame of anti-corruption initiative of Stability Pact (SPAI);

- Institutional capacities of Montenegro in fighting against organized crime;

- Implementation of obligations coming out from the membership in EC (PACO and GRECO);

- Intensifying of the cooperation among competent officials in order to estimate actual situation regarding legislative and

- $\quad$ Providing of technical and financial support.

\section{IV.A.6. Conclusions and Recommendations}

During the analysis, and research of this paper have reached the conclusions and recommendations which first of all will be able to serve others, as a reference point for research and scientific studies regarding the issue challenges the Western Balkan countries in terms of Organized Crime in the field of narco-criminality. Therefore, we present the following conclusions and recommendations: 
-Western Balkan countries all over present transit route for narcotics mainly heroin from Central Asia in terms of Western European countries.

-The experience of the communist system, the economic situation and in most cases the emergence of Western Balkan countries by conflict or war developed has led to the creation of criminal groups dealing with organized crime. Each entity in the Western Balkans plays a key role in the trafficking of narcotics or psychotropic substances.

-The main reason for the high level of organized crime in the Western Balkans after researching and analyzing the factors, also presented a high level of corruption in law enforcement agencies not excluding Courts Prosecutor and state level.

-Different countries are taking every possible measure for preventing and combating narco-criminality by making available the large financial funds and numerous tools to prevent this phenomenon, capturing and bringing the traffickers accountable.

-Exchange of experiences and training of law enforcement regarding narco-criminality and the fight against organized crime in general.

- Strengthening border control from the Western Balkan countries and co-operation may represent one of the most important activities to combat narco-criminality.

-Design and create a strategy within the Western Balkan countries with the aim of unifying all law enforcement agencies for information exchange and joint fight against narco-criminality.

- Creating a regional center which will include all the Balkan countries in order profiling of organized crime groups and the establishment of joint investigation teams.

-established institutions and adopted Laws, according to European standards, in order that Police work gets support by the appropriate Judiciary System;

-implemented the Anti-Corruption Strategy (cooperation with public and implementing of Anti-Corruption Laws);

-strengthened capacities of financial investigation, control of " money laundry" and seizing and confiscating of incomes earned on criminal way;

- provided that Officials of the State Administration possess practical and technical means for fighting against single criminals and organized criminal groups;

-Provided that these measures could be additionally strengthened by better cooperation, exchange of information and coordination within each of countries;

-Provided for public support in fighting against crime on such a way that it will be encouraged the clear message to the public on the need for combating crime.

- Combating and detecting of corruption and organized crime are attained not only by detecting, sentencing and punishing of perpetuators of these criminal offences, although that is one of key elements not only for combating of organized crime, but for stabilizing of legal system, generally. First of all, it is necessary to undertake measures for introducing of European Standards for fighting against organized crime

-Improving of conditions for the work of Judiciary and stabilization of Judiciary System, as well as equipping and introduction of the modern Information System.

-Permanent education, especially in the fields regarding the possibilities of criminal prosecuting of corruption which should have to be connected with influencing onto professional awareness and ethics of judges in order to achieve the higher level of awareness on its danger and harmfulness, as necessary prerequisite for effective work.

-Applying of Judges' Ethic Code, as qualitative basis for establishing of professional criteria etc.

\section{Bibliography}

1. Aleksandar F., (Februar 2004), Organizovani Kriminal i obrisi nove structure Bezbednosti u Evropi (Izvorni naučni rad), Vol. LVI, br. 1. 
[ Balkan Forum, (17-18 June, 2004), Rethinking the Balkans: Incongruities of State and Nation Building, Regional Stabilisation and European Integration, Discussion paper final version, Bertelsmann Foundation and Center for Applied Policy Research, Berlin.

1. Centre for Policy Studies, (2003), In Search of Responsive Government, State Building and Economic Growth in the Balkans, Centre for Policy Studies, CEU (Central European University), Budapest.

q Council of Europe, (2001) Organized Crime Situation Report. Also in: www.coe.int/t/e/legal_affairs/legal.

1. Council of the European Union, November 2012, Report to the Mini-Dublin Group by the Hungarian Regional Chair of the Dublin Group, Regional report on Western Balkans,also in: www.parlament.gv.at/PAKT/EU/XXIV/EU/09/66/.

1. Commission of the European Communities, (2009), Progress Report.

1. Demetropoulou., Leeda, (November 2002) Europe and the Balkans: Membership Aspiration, EU Involvement and Europeanization Capacity in South Eastern Europe, Southeast European Politics, vol. III, no. 2-3.

1] European Union, (2003), Organized Crime Report, EUROPOL, Public Version.

] European Union, (2005), Organized Crime Report, EUROPOL, Public Version.

[. Europian Monitoring Center for Drugs and Drugs Addiction, also in: http://www.emcdda.europa.eu.

1. Europol, OCTA, 2011.

ㅁ Giusto, Sciachitano, (2007), Tiparet Strukturore dhe forma të shfaqjes së krimit të organizuar Transnacional, Tiranë.

[. Latifi, Vesel, (2009), Kriminalistika, Prishtinë.

1 Laušević, D., Mugoša, B. and Ljaljević, A. (1999), Research into attitudes and behaviour of school children and young people on addiction diseases, sexuality and nutrition in the Republic of Montenegro, Health Protection Bureau Podgorica,

1. Los Angelos Taimes, (June, 2011).

口 Lucio, Di., Pietro, (2007), "Mafiet e reja”. Struktura dhe format e shfaqjes së krimit të organizuar transnacional: analizë e përvojës gjyqësore Italiane", Tiranë.

1. Lucia Montanaro-Jankovski, (October, 2005), Good cops, bad mobs? EU policies to fight trans-national organized crime in the Western Balkans, European Policy Center (EPC), Issue Paper No. 40.

[. Milosavljević, Bogoljub, (2003), Reforme obevaštajno-bezbednosnih službi: slucaj Srbije (Translation: "Reform of the Secret-Security Services"), in: Hadžić, Miroslav (ed), Reforma sektora bezbednosti (Translation "Reform of the Security Sector"), G 17 Institut i Centar za civilno-vojne odnose, Beograd, pp. 55-62; Milosavljević, Bogoljub and Aleksandar Resanović, Državno nasilje nad građanima u Jugoslaviji (Translation: "State Violence Directed at the Inhabitants of Yugoslavia"), Centar za antiratnu akciju, Beograd, 2001, at p. 50. Available online at: http://www.caa.org.yu/index.php?page_id=23, shikuar me datë 14/04/2014.

[ Ministry of Health of Montenegro, Strategy of Montenegro for the Prevention of Drug Abuse 2013-2020, Estimated number of heroin users in 2011.

1. Mugoša, B., Đurišić ,T. and Golubović, L. (2008), ESPAD European school survey project on tobacco, alcohol and drugs: National report, Montenegro, Public Health Institute, Podgorica.

[. Mugoša, B. (2009), 'Epidemiological study on drug use among school children in the Republic of Montenegro', Ph.D. dissertation, Faculty of Medicine of Kragujevac University, Kragujevac.

[ Program of Fighting against Corruption and Organized Crime, (May 2005), Republic of Montenegro Ministry of Interior.

[ Radovanovik, Tamara, (2012), Nga "ballkanizmi" në "europianizimin" e shteteve të Ballkanit Perëndimor, Çështje Europiane dhe të Sigurisë 23, Instituti për Demokraci dhe Ndërmjetësim, Tiranë.

q Raporti i CEO, (2005), Krimi i Organizuar përmban kërcenim për demokracinë Evropiane.

[. Raport Informues për Media, Policia e Kosovës, 2011. 
[ Ristić, B.,. 3 November 2002, "Whose Arm Runs Serbia?" Glas Javnosti [Belgrade], (FBIS Document EUP 20021104000406).

[ Robert M. Hayden, (Winter, 1992), Constitutional Nationalism in the Formerly Yugoslav Republics, (Slavic Review), Vol. 51, No.4.

[ Serious and Organized Crime Threat Assessment in Montenegro, Ministry of the Interior Police Directorate, Podgorica, 2014,

[ United Nations, Office on Drugs and Crimes, March 2008, Crime and its Impact on the Balkans.

[. United Nations Office on Drugs and Crimes, (2011), The transatlantic cocaine market.

[ United Nations, Office on Drugs and Crime, (N.York 2008), Bulletin on Narcotics Volume LVIII, Nos. 1 and 2, Review of the, world cannabis situation.

[ United Nations Office on Drugs and Crimes, March 2014, The illicit drug trade through South-Eastern Europe, Vienna.

[ United Nations, Office on Drugs and Crimes, (2009), Balkan Study.

Web portals:

Novinar Online 17 May 2007, "Veliki Pljackasi i Dileri Evrope", http://www.novinar.de/2007/05/17/veliki-pljackasi-i-dilerievrope.html,

The Guardian, (5 June 2014), Montenegro customs seize $250 \mathrm{~kg}$ of cocaine smuggled under bananas, http://www.theguardian.com/world.

European Monitoring Center for Drugs and Drugs Addiction, (Montenegro 2011), http://www.emcdda.europa.eu/publications/country. 